\title{
HUBUNGAN PENGETAHUAN IBU TENTANG ASI EKSKLUSIF TERHADAP PEMBERIAN ASI EKSKLUSIF
}

\section{The Corelation Of Mother's Knowledge About Exclusive Breastfeeding To Exclusive Breastfeeding}

\section{Elma Monica Putri ${ }^{\text {* }}$ \\ Rizki Muji Lestari ${ }^{2}$ \\ Dita Wasthu Prasida ${ }^{3}$}

\author{
*123 STIKES Eka Harap, Palangka \\ Raya ,Kalimantan Tengah, \\ Indonesia
}

*email:

elmaputri999@gmail.com

\section{Kata Kunci: \\ Pengetahuan \\ ASI Eksklusif}

Keywords:

Knowledge

Exclusive Breastfeeding

\begin{abstract}
Abstrak
Latar Belakang : Tidak memberikan ASI menyumbang angka kematian bayi karena buruknya status gizi yang berpengaruh pada kesehatan bayi dan kelangsungan hidup bayi. Data pemantauan status gizi di Indonesia tahun 2017 menunjukkan cakupan pemberian ASI secara eksklusif selama 6 bulan pertama oleh ibu untuk bayinya masih sangat rendah yaitu $35,7 \%$. Artinya ada sekitar $65 \%$ bayi yang tidak mendapatkan ASI secara eksklusif selama 6 bulan pertama lahir. Angka masih jauh dari target cakupan ASI Eksklusif pada 2019 yang ditetapkan oleh World Health Organization (WHO) maupun Kementerian Kesehatan yaitu 50\%.

Tujuan : Tujuan yang ingin dicapai dalam penelitian ini adalah untuk mengetahui hubungan pengetahuan ibu tentang ASI Eksklusif terhadap pemberian ASI Eksklusif. Metode : Metode penelitian yang digunakan dalam penelitian ini adalah literatur review dengan menganalisis jurnal tentang pengetahuan tentang ASI Eksklusif terhadap pemberian ASI Eksklusif dari Google Schoolar antara tahun 20 I7-2020.

Hasil : Hasil penelitian ada lima (5) jurnal menyatakan ada hubungan pengetahuan tehadap pemberian ASI Ekslusif dengan $p$-value $<0,05$ dan satu (I) artikel yang tidak hubungan pengetahuan tehadap pemberian ASI Ekslusif $p$-value $>0,05$.

Kesimpulan: Hasil penelitian pengetahuan sangat erat hubungannya dengan pemberian ASI Eksklusif. Adanya konselor ASI bagi ibu dari masa kehamilan dapat membantu meningkatkan pengetahuan ibu ASI Eksklusif.
\end{abstract}

\begin{abstract}
Beground : Not giving breastfeeding contributes to infant mortality due to poor nutritional status which effects infant health and infant survival. Monitoring of data on nutritional status of Indonesia in 2017 showed that the coverage of giving exclusive breastfeeding for the first 6 months by mothers for their infant is still very low at 35.7\%. This means there are about $65 \%$ of infant are not getting exclusively breastfeeding during the first 6 months of birth. The figure are still far from the coverage of exclusive breastfeeding target in 2019 set by the World Health Organization (WHO) and the Ministry of Health, which is $50 \%$.

The purpose : The aim of this study was to determine the relationship between knowledge about exclusive breastfeeding and exclusive breastfeeding.

Methode : The research method used in this study is a literature review by analyzing journals about knowledge about exclusive breastfeeding on exclusive breastfeeding from Google Schoolar between 2017-2020.

The result : The results of the research are there 5 journals stating that there was a relationship between knowledge againts giving exclusive breastfeeding with p-value $<0.05$ and I journal that had no knowledge relationship againts giving exclusive breastfeeding with $p$-value $>0.05$.

Conclusion : The results of knowledge research are closely related to exclusive breastfeeding. The existence of breastfeeding counselors for mothers during pregnancy can help increase the knowledge of exclusive breastfeeding mothers.
\end{abstract} Palangkaraya. This is Open Access article under the CC-BY-SA License (http://creativecommons.org/licenses/by-sa/4.0/). DOI: https://doi.org//0.33084/jsm.vxix.xxx.

\section{PENDAHULUAN}

Air Susu Ibu (ASI) merupakan makanan pertama, utama dan terbaik untuk bayi, yang bersifat alamiah. ASI mengandung berbagai zat gizi yang dibutuhkan dalam proses pertumbuhan dan perkembangan bayi. Tidak memberikan ASI menyumbang angka kematian bayi karena buruknya status gizi yang berpengaruh pada kesehatan bayi dan kelangsungan hidup bayi 
(Muslimah et al., 2020). Rendahnya tingkat pemahaman tentang pentingnya ASI selama 6 bulan pertama kelahiran bayi dikarenakan kurangnya pengetahuan yang dimiliki oleh para ibu mengenai segala nilai plus nutrisi dan manfaat yang terkandung dalam ASI (Fatimah \& Oktavianis, 2019). Akibatnya program pemberian ASI eksklusif tidak berlangsung secara optimal (Yanuarini et al., 2017).

World Health Organization (WHO) melaporkan bahwa secara global rata-rata angka pemberian ASI eksklusif di dunia tahun 2017 sebesar 38\%, WHO menargetkan tahun 2025 angka pemberian ASI Eksklusif pada usia 6 bulan pertama kelahiran meningkat setidaknya $50 \%$. Data pemantauan status gizi di Indonesia tahun 2017 menunjukkan cakupan pemberian ASI secara eksklusif selama 6 bulan pertama oleh ibu untuk bayinya masih sangat rendah yaitu 35,7\%. Artinya ada sekitar $65 \%$ bayi yang tidak mendapatkan ASI secara eksklusif selama 6 bulan pertama lahir. Angka masih jauh dari target cakupan ASI Eksklusif pada 2019 yang ditetapkan oleh World Health Organization (WHO) maupun Kementerian Kesehatan yaitu $50 \%$. Pengetahuan ibu masih menjadi faktor utama perilaku pemberian ASI Eksklusif (Larasati, 2017). Dari data Profil Kesehatan Kota Palangka Raya tahun 2017 cakupan ASI eksklusif masih dibawah target, pada tahun 2017 sebesar 16,79\%. Rendahnya cakupan ASI eksklusif, merupakan tantangan bagi para bidan puskesmas dan pengelola KIA di Dinas Kesehatan Kota Palangka Raya, untuk lebih giat melakukan promosi kesehatan tentang pentingnya ASI Eksklusif bagi pertumbuhan bayi. Cakupan pemberian ASI eksklusif di Kalimantan Tengah yaitu 80\%. Data Riskesdas Kota Palangka Raya Tahun 2017 menunjukkan rendahnya cakupan pemberian ASI Eksklusif di Kota Palangka Raya yaitu 16,8\%. Pada tahun 2019 cakupan ASI Eksklusif di Kota Palangka Raya yaitu sebesar 49,25\%. Persentase tertinggi cakupan pemberian ASI ekskusif di Kabupaten Barito Utara sebesar 76,1\% kemudian Kabupaten Lamandau sebesar 72,3\%, sedangkan persentase terendah terdapat di Kabupaten Gunung Mas sebesar 17,3\% dan kabupaten Katingan sebesar $19,7 \%$, sehingga dapat dilihat terjadinya peningkatan pemberian ASI eksklusif di Kota Palangka Raya, tetapi masih di bawah target pemerintah yaitu sebesar $80 \%$ (Dinas Kesehatan Provinsi Kalimantan Tengah, 2019). Banyak faktor yang mempengaruhi rendahnya jumlah ibu yang memberi ASI eksklusif antara lain pengetahuan ibu tentang pentingnya ASI eksklusif masih rendah (Elizabeth, 2018). Kurangnya pengetahuan ibu tentang manfaat ASI menyebabkan ibu-ibu mudah terpengaruh dan beralih ke susu formula. Tingkat pengetahuan yang tinggi menentukan mudah tidaknya ibu untuk memahami dan menyerap informasi tentang ASI eksklusif. Semakin tingginya tingkat pengetahuan ibu, maka makin tinggi pula ibu dalam menyerap informasi tentang ASI Eksklusif (Fatimah \& Oktavianis, 2019). Kurangnya pengertian dan pengetahuan ibu tentang ASI menyebabkan ibu-ibu akan mudah terpengaruh dan akhirnya beralih menggunakan susu formula. Rendah pengetahuan ibu tentang ASI dirasa wajar karena informasi atau nasihat diberikan nakes juga dirasa masih kurang. Hanya sebagian kecil saja ibu yang mendapatkan informasi atau nasihat tentang ASI dengan benar (Noorbaya et al., 2017).

Hasil penelitian yang dilakukan Widya Fadila dan Ramadhana Komala (2018) Berdasarkan hasil penelitian hubungan pengetahuan dengan pemberian ASI eksklusif dari 24 responden yang pengetahuan kurang baik terdapat $87,5 \%$ ibu dan tidak memberikan ASI eksklusif kepada bayinya. Setelah dianalisis dengan uji chi square menggunakan tingkat kesalahan $5 \%$, didapatkan $P$-value $=0,036(P$-value $<\alpha \quad 0,05)$, sehingga dapat disimpulkan bahwa ada hubungan pengetahuan dengan pemberian ASI Eksklusif. Hasil analisis diperoleh nilai $O R=7,000$ yang berarti bahwa ibu yang pengetahuannya kurang baik akan memilki resiko 7,000 kali untuk tidak memberikan ASI eksklusif kepada 
bayinya dibandingkan ibu yang pengetahuannya baik (Aisyah, 2018).

Penelitian yang dilakukan di oleh Widad Abdullah Sjawie, Adisti A. Rumayar, Grace E.C. Korompis (2019). Sampel dalam penelitian ini yaitu 75 ibu yang memiliki bayi 6-12 bulan. Pengambilan sampel menggunakan teknik acidental sampling. Pengumpulan data melalui wawancara dengan menggunakan kuesioner. Hasil analisis data univariat menunjukkan sebagian besar ibu memiliki pengetahuan kurang baik $(66,7 \%)$ terdapat hubungan antara pengetahuan dengan pemberian ASI eksklusif (Eksklusif et al., 2019).

Penelitian yang dilakukan oleh Derma Wani Damanik (2019). Hasil analisis dengan program SPSS diperoleh nilai statistik p-value $0.01<0,05$, nilai $X^{a}$ 10.848a sehingga hipotesa nol (HO) ditolak yang berarti ada hubungan yang signifikan antara pengetahuan ibu dengan pemberian ASI Eksklusif diwilayah kerja Puskesmas Perdagangan Simalungun. Ada hubungan yang signifikan antara pengetahuan ibu dengan pemberian ASI eksklusif di wilayah kerja Puskesmas Perdagangan Kabupaten Simalungu (Damanik, 2020).

Berdasarkan penjelasan di atas maka di sarankan bagi pengelola laporan untuk lebih teliti dalam sistem pencatatan dan pelaporan, juga lebih meningkatkan koordinasi dan pengelola program terkait, terutama tentang persamaan persepsi terhadap definisi operasional tentang ASI eksklusif. Sebagai petugas promosi kesehatan, pengetahuan petugas harus ditingkatkan melalui informasi terbaru dengan pelatihan sehingga muncul inovasi kreatif terkait promosi ASI eksklusif dengan metode penyuluhan yang lebih baik lagi dan menarik di bantu dengan media promosi kesehatan agar informasi yang diberikan dapat tersampaikan dengan baik (Ezafitria, 2017).

\section{METODOLOGI}

Penelitian ini merupakan penelitian Studi Literature Review yang dimana bahwa dijelaskan Literature Review adalah uraian tentang teori, temuan, dan bahan penelitian lainnya yang diperoleh dari bahan acuan yang akan dijadikan landasan kegiatan penelitian untuk menyusun kerangka pemikiran yang jelas dari perumusan masalah yang ingin diteliti oleh peneliti (Nurislaminingsih et al., 2020).

Pada penelitian literatur review ini judul yang di analisis adalah Hubungan Pengetahuan Ibu Tentang ASI Eksklusif Terhadap Pemberian ASI Eksklusif.

\section{HASIL DAN PEMBAHASAN}

Hasil penelitian dengan menggunakan literatur review dari 6 (enam) jurnal yang dianalisis di temukan 5 (lima) jurnal yang ada hubungan pengetahuan ibu terhadap pemberian ASI eksklusif dan I (satu) jurnal tidak ada hubungan pengetahuan ibu terhadap pemberian ASI Eksklusif. Hasil penelitian Derma Wani Damanik (2020) menunjukkan bahwa mayoritas pengetahuan ibu tentang pemberian ASI eksklusif berada pada kategori kurang baik, yaitu pengetahuan baik sebesar 32,2\% dan kurang baik sebesar 67,8\%. Hasil uji statistik menunjukkan bahwa $p$-value sebesar 0,0I yang berarti nilai $p$-value $<0,05$ sehingga hipotesa $\mathrm{HO}$ ditolak diperoleh bahwa ada hubungan yang signifikan antara pengetahuan ibu dengan pemberian ASI Eksklusif. Hasil penelitian Widad Abdullah Sjawie, Adisti A. Rumayar,Grace E.C. Korompis (2019) menunjukkan bahwa tingkat pengetahuan tergolong kurang baik yaitu pengetahuan baik sebesar 33,3\% dan pengetahuan menunjukkan terdapat hubungan antara pengetahuan dengan pemberian ASI Eksklusif mendapatkan nilai probabilitas 0,000 yaitu lebih kecil dari nilai $\alpha=0,05$. Hasil penelitian Widya Fadila, Ramadhana Komala (2018) menunjukkan pengetahuan baik sebesar 33,3\% dan pengetahuan kurang sebesar 66,7\%. Hasil uji chisquare didapatkan $p$-value $=0,012(p$-value $<\alpha \quad 0,05)$. kurang baik sebesar $66,7 \%$. Hasil chi-square 
Sehingga dapat disimpulkan ada hubungan pengetahuan ibu dengan pemberian ASI Eksklusif. Hasil penelitian Nurleli, Jenny Marlindawani Purba, Rinawati Sembiring menunjukkan pengetahuan baik sebesar $61,1 \%$ dan pengetahuan kurang sebesar 38,9\%. Hasil penelitian menunjukkan bahwa pengetahuan ibu tentang ASI eksklusif memiliki hubungan signifikan dengan tindakan pemberian ASI eksklusif ( $p$-value < 0,05). Hasil penelitian Syera Mahyuni (2017) menunjukkan bahwa responden yang memiliki tingkat pengetahuan yang baik tentang ASI eksklusif sebanyak 27 orang (67,50 \%) dengan kriteriapekerjaan ibu sebagai pegawai negeri sebanyak 5 orang (12,5\%), pegawai swastasebanyak 4 orang (10,0\%), dan sebanyak 18 orang $(45,00 \%)$ hanya berprofesi sebagai ibu rumah tangga saja. Responden yang memiliki tingkat pengetahuan tentang ASI eksklusif cukup sebanyak 8 orang (20 \%) yaitu sebanyak I orang (2,5 \%) memiliki pekerjaan sebagaipegawai swasta, I orang $(2,5 \%)$ memiliki pekerjaan sebagai wiraswasta dan sebanyak 6 orang (I5\%) berprofesi sebagai ibu rumah tangga. Responden yang memiliki tingkat pengetahuan tentang ASI eksklusif yang kurang sebanyak 5 orang (12,50 \%) yaitu berprofesi sebagai ibu rumah tangga. Berbanding terbalik dengan penelitian Riza Ramli menunjukkan pengetahuan baik sebesar $85,7 \%$ dan pengetahuan kurang baik sebesar 94,4\%. Hasil uji analisis bivarit diketahui bahwa tidak ada hubungan antara pengetahuan ibu dengan pemberian ASI Eksklusif $p$ value $=0,346>0,05$.

\section{KESIMPULAN}

Kesimpulan yang diperoleh dari penelitian ini adalah :

I. Tingkat pendidikan perempuan merupakan salah satu faktof yang mempengaruhi kejadian stunting, dan tingkat pendidikan perempuan di Provinsi Kalimantan Tengah berada pada level "Kurang", serta hasil analisis menunjukkan terdapat hubungan signifikasi antara tingkat pendidikan perempuan terhadap kejadian stunting di Kalimantan Tengah.

2. Pemberian ASI ekslusif pada balita di provinsi Kalimantan Tengah merupakan salah satu faktor yang mempengaruhi kejadian stunting, hal ini ditunjukan terdapatnya signifikasi antara pemberian ASI ekslusif terhadap kejadian stunting di Kalimantan Tengah

\section{UCAPAN TERIMA KASIH}

Puji syukur penulis panjatkan kepada Tuhan Yang Maha Esa, karena atas berkat dan rahmat-Nya penulis dapat menyelesaikan skripsi dengan judul "HUBUNGAN PENGETAHUAN IBU TENTANG ASI EKSKLUSIF TERHADAP PEMBERIAN ASI

EKSKLUSIF”. Penulisan skripsi ini dilakukan dalam rangka memenuhi salah satu syarat untuk mencapai gelar Sarjana Kesehatan Masyarakat pada Sekolah Tinggi Ilmu Kesehatan Palangka Raya. Penulis menyadari bahwa, tanpa bantuan dan bimbingan dari berbagai pihak pada penyusunan skripsi ini, sangatlah sulit bagi penulis untuk menyelesaikan skripsi ini. Oleh karena itu, penulis mengucapkan terima kasih kepada yang terhormat :

I. Maria Adelheid Ensia, S.Pd., M.Kes. Selaku Ketua STIKES Eka Harap Palangka Raya yang telah menyediakan sarana dan prasarana kepada penulis dan mengikuti pendidikan di STIKES Eka Harap Palangka Raya.

2. Lensi Natalia Tambunan, SST., M.Kes. selaku Ketua Program Studi Sarjana Kesehatan Masyarakat STIKES Eka Harap Palangka Raya.

3. Mariaty A. Sangkai, S.Pd, M.Kes selaku Penguji yang selalu memberikan masukan yang sangat berarti untuk tugas akhir ini

4. Rizki Muji Lestari, SST, M.Kes selaku Pembimbing I dan Anggota Tim Penguji yang telah bersedia membantu dan membimbing saya dalam 
pembuatan skripsi ini, sehingga skripsi ini dapat terselesaikan dengan tepat waktu.

5. Bd. Dita Wasthu Prasida, SKM, M.Kes (Epid) selaku pembimbing II dan Anggota Tim Penguji yang juga telah membantu saya dalam menyelesaikan skripsi ini dan bersedia membagikan ilmunya dalam membantu saya menyelesaikan skripsi ini.

6. Kepada orang tua saya, terima kasih atas dukungan serta doa yang selalu diberikan kepada saya, terlebih lagi kepada Tuhan Yesus karena atas penyertaan dan berkat - Nya saya dapat menyelesaikan skripsi saya tepat waktu.

7. Kepada sahabat - sahabat saya yang telah memberikan bantuan, masukan dan saran dalam menyelesaikan skripsi ini.

Peneliti mengakui masih banyak terdapat kekurangan dari skripsi ini. Oleh karena itu peneliti sangat mengharapkan kritik dan saran yang bersifat membangun untuk kesempurnaan skripsi ini. Akhir kata, peneliti berharap skripsi ini dapat memberikan manfaat bagi pengembangan ilmu pengetahuan terutama bidang riset kesehatan masyarakat, baik di masa sekarang maupun di masa yang akan datang, semoga Tuhan Yang Maha Esa senantiasa memberikan rahmat dan karunia-Nya kepada kita semua.

\section{REFERENSI}

I. Muslimah, A., Laili, F., \& Saidah, H. (2020). Pengaruh Pemberian Kombinasi Perawatan Payudara Dan Pijat Oksitosin Terhadap Produksi ASI Pada Ibu Post Partum. Jurnal Mahasiswa Kesehatan, I(2), 87-94.

2. Fatimah, S., \& Oktavianis, T. W. (2019). Hubungan Pengetahuan Ibu Tentang Manajemen Laktasi Dengan Pemberian Asi Eksklusif Di Wilayah Kerja Puskesmas Kelurahan Bidara Cina I Jakarta Timur Tahun. 4(d), 627.

3. Yanuarini, T. A., Rahayu, D. E., \& Prahitasari, E. (2017). Hubungan Pengetahuan Dengan Sikap Ibu dalam Pemberian ASI Eksklusif di Wilayah Kerja Puskesmas Pranggang Kabupaten Kediri. Jurnal Ilmu Kesehatan, $3(\mathrm{I})$,
https://doi.org//0.3283I/jik.v3il.39

4. Larasati, P. A. (2017). Hubungan Dukungan Suami dengan Keberhasilan ASI Eksklusif di Wilayah Kerja Puskesmas Jetis II Bantul. I-I3.

5. Dinas Kesehatan Provinsi Kalimantan Tengah. (2019).

6. Dinas Kesehatan Provinsi Kalimantan Tengah. Dinas Kesehatan Provinsi Kalimantan Tengah, 09, 76. http://www.dinkes.kalteng.go.id/haldownload-.html

7. Elizabeth, G. s. (20/8). Pemberian Asi Eksklusif Dalam Pemenuhan Gizi Bayi Umur 0-6 Bulan. Majalah Ilmiah Methoda, 8(April), 95-100.

8. Noorbaya, S., Llyod, S. S., \& Putri, Y. E. (2017). Faktor-Faktor Yang Mempengaruhi Rendahnya Cakupan Asi Eksklusif Pada Bayi Umur 0-6 Bulan Di Bidan Praktik Salasiah Gun Kecamatan Palaran Samarinda Tahun 2017. In Jurnal Kebidanan Mutiara Mahakam (Vol. 5, Issue 2, pp. 68-72). http://jurnal.akbidmm.ac.id/index.php/jkmm/article/ view/19

9. Aisyah, J. G. (2018). Journal Gizi Aisyah.

10. Eksklusif, A. S. I., Wilayah, D. I., Puskesmas, K., \& Kota, T. (2019). Hubungan Antara Pengetahuan Dan Sikap Ibu Dengan Pemberian Asi Eksklusif Di Wilayah Kerja Puskesmas Tuminting Kota Manado. Kesmas, 8(7), 298-304.

II. Damanik, D. (2020). Hubungan Pengetahuan Ibu Dengan Pemberian Asi Eksklusif Di Wilayah Kerja Puskesmas Perdagangan Kabupaten Simalungun. Jurnal Keperawatan Priority, 3(I), 58. https://doi.org/10.34012/jukep.v3il.798

12. Ezafitria, N. (20I7). Studi Fenomenologi Promosi Kesehatan Dalam Program Asi Eksklusif Di Kota Bukittinggi. Human Care Journal, 2(2), 153-162. https://doi.org//0.32883/hcj.v2i2.120

13. Nurislaminingsih, R., Rachmawati, T. S., Winoto, D. Y., Raya, J., Sumedang, B., 2I, K. M., \& Barat, J. (2020). Pustakawan Referensi Sebagai Knowledge Worker. Anuva, 4(2), 169-182.

14. Arini Putri. (2018). Konsep Pengetahuan.

15. Maharani, N. (20I8). ASI Eksklusif. Journal of Chemical Information and Modeling, 53(9), 16891699.

16. Nurdiana. (2019). Air Susu Ibu (ASI). Journal of Chemical Information and Modeling, 53(9), 16891699. 
17. Usman, A. G., Saleh, L. M. I., Negeri, M., Mangkurat, L., Kalimantan, P., \& Usman, A. G. (1998). Bab i pendahuluan a. latar belakang. 2, I

18. Yusrina, A., \& Devy, S. R. (2017). Faktor Yang Mempengaruhi Niat lbu Memberikan Asi Eksklusif Di Kelurahan Magersari, Sidoarjo. Jurnal PROMKES, 4(I),

II.

https://doi.org/ | 0.20473/jpk.v4.i I.20 I6. I I-2 I 